\title{
Practices of Infection Control Among Dental Care Providers: A Cross Sectional Study
}

This article was published in the following Dove Press journal:

Clinical, Cosmetic and Investigational Dentistry

\author{
Arwa M Mahasneh (1) \\ Maram Alakhras iD ${ }^{2}$ \\ Omar F Khabour iD ${ }^{3}$ \\ Amani G Al-Sa'di ${ }^{4}$ \\ Dana S Al-Mousa (iD) ${ }^{2}$ \\ 'Department of Applied Dental Sciences, \\ Jordan University of Science and \\ Technology, Irbid 22II0, Jordan; \\ ${ }^{2}$ Department of Allied Medical Sciences, \\ Jordan University of Science and \\ Technology, Irbid 22II0, Jordan; \\ ${ }^{3}$ Department of Medical Laboratory \\ Sciences, Jordan University of Science \& \\ Technology, Irbid 22। I0, Jordan; \\ ${ }^{4}$ Technical Coordination and Consumer \\ Education Section of the Jordanian Food \\ and Drug Administration, Irbid 221 I0, \\ Jordan
}

Background: A wide range of microorganisms poses a threat to patients and dental care teams. Implementation of safety guidelines is thus essential to prevent infection in dental clinics.

Aim: To investigate the level of infection-control practices among dental health-care providers in Jordan.

Methods: A self-administered questionnaire was distributed to dental care providers from hospitals, academic institutions, and dental centres. The questionnaire covered sociodemographic variables, professional characteristics, and recommended guidelines of infection control.

Results: A total of 190 questionnaires were obtained out of 500 distributed questionnnaires (response rate: $38 \%$ ). Females accounted for $62.6 \%$ of the sample and $64.7 \%$ were dentists. The majority was vaccinated against hepatitis B (82.1\%) and wash their hands as usual behavior before $(66.3 \%)$ and after $(83.2 \%)$ treatment. Approximately $87.9 \%$ wear gloves and $78.9 \%$ wear masks while performing dental procedures. Autoclave sterilization and punctureresistant containers for sharp instruments were used by $90.5 \%$ and $88.4 \%$, respectively. The majority $(81.0 \%)$ had protocols for emergency treatment of needle stick or other sharps accidents. High volume evacuation was used in $28.6 \%$ of public hospitals compared to $19.4 \%$ in academic institutions $(\mathrm{P}<0.01)$. In addition, surface barriers for dental unit surfaces were used by $70.2 \%$ of private dental clinics, $50 \%$ of public hospitals, and $36.1 \%$ of academic institutions $(\mathrm{P}<0.001)$. Finally, compared to dentists, dental support staff showed low compliance with infection-control guidelines.

Conclusion: The overall practice of infection-control measures among the participants is very good. Educational programs and training strategies should be implemented to maximize and enhance the compliance of the dental care providers with infection-control guidelines.

Keywords: infection control, dental care providers, vaccination, sterilization, disinfection

\section{Introduction}

In dentistry, a wide range of microorganisms poses a threat to patients and dental care providers such as Mycobacterium tuberculosis, hepatitis viruses, staphylococci, streptococci, herpes simplex virus types, human immunodeficiency virus, mumps, influenza, rubella and others. ${ }^{1}$ In dental environment, pathogens can be transmitted through direct contact with infected blood, saliva, or other body fluids; or indirectly via contaminated instruments, materials and surfaces. ${ }^{2}$ In addition, pathogens can be transmitted through inhalation of airborne pathogens in splattered droplets or aerosols from saliva and respiratory fluid., ${ }^{2,3}$ The Infection-Control Practices for Dentistry was among the first guidelines for the prevention of
Correspondence: Arwa M Mahasneh Department of Applied Dental Sciences, Jordan University of Science and Technology, P.O.Box 3030, Irbid 22110, Jordan

Tel +962796357733

Email ammahasneh@just.edu.jo 
infection by blood and body fluids of patients. ${ }^{1}$ According to these guidelines, all patients should be treated as potentially infectious in order to prevent disease transmission. ${ }^{1,4}$ Therefore, implementing infection-control precautions is the standard of care to protect both patients and dental care professionals and to ensure a safe working environment. Among such precautions are personal protective equipment (PPE), hand hygiene, waste management and sterilization. $^{5}$

Preventing infection exposure in dental care settings can also be achieved efficiently by immunization. ${ }^{6}$ Therefore, many dental education institutions and dental care facilities have a comprehensive immunization policy for their students and dental care providers. ${ }^{7}$ However, most patients are not similarly protected, which may increase the risk of transmission of infectious diseases between patients. ${ }^{6}$ PPE such as gown, gloves, face mask and eye protection have been shown to be an effective means of preventing the transmission of pathogens. ${ }^{89}$ However, any failure to comply with implementing infection-control measures can harm both patients and heathcare teams. $^{4,5}$

In Jordan, few studies have evaluated the level of infection control in dental practice. These studies were limited either to one institution, ${ }^{10}$ private dental clinics ${ }^{11}$ or to dental technicians in commercial dental laboratories. ${ }^{12}$ Therefore, the aim of this study was to evaluate the level of infection-control practices among dentists and dental care providers in the different dental sectors in Jordan. In addition, the study examined the association between sociodemographic and professional characteristics of the participants and their practice of infection-control measures.

\section{Materials and Methods}

\section{Study Design and Instrumentation}

This cross-sectional survey was conducted between January and April 2019. Institutional Review Board approval was granted by the Jordan University of Science and Technology (305-2018). The study involved a self-administered questionnaire that was distributed to a convenient sample of the dentists, and dental care providers from eight public hospitals ( 2 Military, 4 governmental and 2 University affiliated hospitals) and 30 public and private dental clinics from North Jordan and the capital city. The questionnaire was developed in English and was based on the Guidelines for Infection Control in Dental Health Care Settings of the US Centers for
Disease Control and Prevention. ${ }^{13}$ The questionnaire was pilot tested on 20 participants to ensure its clarity and content validity. The questionnaire was divided into several sections. The first section collected personal sociodemographic variables (age, sex, specialty, and university degree). The second section collected information about the professional characteristics of participants. The last part was about the participants' practice of vaccination, personal protective equipment, hand hygiene, waste management and sterilization. Data entry was reviewed by random audit of $10 \%$ of the entered information. The questionnaire is available upon request from the corresponding author.

\section{Participants}

The target population of the current study is approximately 5000 dental care providers who are responsible for applying the infection-control guidelines in the dental setting. To have a good representation of the target population, a total of five hundred subjects $(10 \%)$ were invited to complete the questionnaire. One hundred and ninety participants agreed to complete the questionnaire by signing the consent form. Participation was voluntary and questionnaires were not identified by name or code to maintain anonymity and confidentiality. Access to data was restricted to the research team.

\section{Data Analysis}

Data analysis was conducted using the Statistical Package for Social Sciences (SPSS) software version 21.0 (SPSS ${ }^{\circledR}$ : Inc., Chicago, IL, USA). Frequencies and percentages were produced. Chi- square test was used to compare between subgroups. The level of significance was set at $(\mathrm{P} \leq 0.05)$.

\section{Results}

\section{Demographics and Work Characteristics of the Study Sample}

The response rate was 38\% (190 out of 500). Table 1 shows the demographic characteristics of the study participants. About two third (60.5\%) of the sample were older than 30 years. Females accounted for $62.6 \%$ of respondents and approximately $52.6 \%$ held bachelor degrees. Two thirds of respondents were dentists while the remainder were members of the dental support staff. The mode of practice of the clinic showed that $52.6 \%$ worked in general dentistry and the remainder were from specialty practices. 
Table I Demographic and Work Characteristics ( $N=190)$

\begin{tabular}{|l|l|}
\hline Variable & $\mathbf{N}(\%)$ \\
\hline Age (Years) & \\
$<30$ & $75(39.5)$ \\
$30-39$ & $63(33.2)$ \\
$\geq 40$ & $52(27.4)$ \\
\hline Gender & \\
Male & $71(37.4)$ \\
Female & $119(62.6)$ \\
\hline Educational level & \\
High school & $12(6.3)$ \\
Diploma & $41(21.6)$ \\
Bachelor & $100(52.6)$ \\
Higher education & $37(19.5)$ \\
\hline Profession & \\
Dentists & $123(64.7)$ \\
Dental support staff & $67(35.3)$ \\
\hline Mode of practice of the clinic & \\
Speciality & $90(47.4)$ \\
General practice & $100(52.6)$ \\
\hline Region of practice & \\
Northern Jordan & $111(58.4)$ \\
Capital city & $79(41.6)$ \\
\hline Practice type & \\
Private clinics & $34(44.2)$ \\
Academic institutions & $70(36.8)$ \\
Public hospital/centres & \\
\hline
\end{tabular}

The majority of participants were from Northern Jordan (58.4\%) and approximately one fifth (18.9\%) were from academic institutions.

\section{Practice of Infection Control Among Study Participants Vaccination Against Hepatitis B}

Results revealed that $82.1 \%$ of participants were vaccinated against hepatitis $\mathrm{B}$. The distribution of the nonvaccinated fraction was $34.4 \%$ of dental support staff and 9.9\% of dentists $\left(\chi^{2}=19.15 ; \mathrm{P}<0.0001\right)$. In addition, diploma/high school degree holders tended to be unvaccinated compared with participants holding other degrees $\left(31.7 \%\right.$ vs $39.6 \%$, respectively, $\left.\chi^{2}=25.83 ; \mathrm{P}<0.001\right)$. With respect to other demographic variables, there were no statistical significant differences regarding hepatitis $B$ vaccination.

\section{Hand Hygiene Practices}

Table 2 summarizes the practice of hand hygiene, use of personal protective equipment, and sterilization and disinfection among participants. The majority of respondents reported practiced hand washing after treatment $(83.2 \%)$ and prior to starting treatment $(66.3 \%)$. About one-half (45.8\%) reported usually washing hands before wearing gloves. With respect to materials used in handwashing, $49.5 \%, 32.1 \%$, and $27.9 \%$ reported washing their hands using plain soap, hand sanitizer and antiseptic solutions, respectively.

There was no statistically significant difference regarding practicing hand hygiene by demographic and work characteristics except in specific areas as shown by bivariate analysis in Table 3. Females (26.1\%) rarely washed their hands before wearing gloves compared with male (9.9\%) subjects $\left(\chi^{2}=7.3 ; \mathrm{P}=0.026\right)$. Dental support staff (19.4\%) reported that they rarely wash their hands before starting patient care compared to only $4.9 \%$ of dentists $\left(\chi^{2}\right.$ $=10.36 ; \mathrm{P}=0.006)$. Participants with a diploma degree reported that they always wash their hands after patient treatment at a lower proportion compared with the others $\left(\chi^{2}\right.$ value $\left.=13.37 ; \mathrm{P}=0.038\right)$. Approximately $41.0 \%$ of participants from specialty clinics reported that they always use hand sanitizer instead of washing hands compared with $24.0 \%$ of those in general practice clinics $\left(\chi^{2}\right.$ value $\left.=12.17 ; \mathrm{P}=0.002\right)$.

\section{Using Personal Protective Equipment}

The majority of participants reported an acceptable level of personal protective equipment use (Table 2). This includes constantly wearing gloves while performing dental procedures $(87.9 \%)$, changing gloves between patients (89.5\%), wearing sterile surgical gloves (63.7\%) and masks $(78.9 \%)$ while performing surgical dental operations, and using single ampoules for local anaesthetic injections (82.1\%). Table 3 shows that approximately onefourth of the study sample reported that they frequently use high volume evacuators, with significant differences between public hospitals $(28.6 \%)$ and academic institutions $(19.4 \%) \quad\left(\chi^{2}=30.23 ; \mathrm{P}<0.0001\right)$. In addition, about $40.0 \%$ of the sample employs preprocedural mouth rinsing. In this regard, participants aged 40 years and older employ preprocedural mouth rinsing more frequently than those participants in other age ranges $\left(\chi^{2}=10.71, \mathrm{P}=0.030\right)$. 
Table 2 Infection-Control Practices in the Study Sample ( $N=190)$

\begin{tabular}{|c|c|c|c|}
\hline \multirow{2}{*}{ Variable } & \multicolumn{3}{|c|}{ Response $\mathbf{N}(\%)$} \\
\hline & Always & Occasionally & Rarely/None \\
\hline \multicolumn{4}{|l|}{ Hand hygiene } \\
\hline Washing hands before patient treatment & $126(66.3)$ & $45(23.7)$ & $19(10.0)$ \\
\hline Washing hands after patient treatment & $158(83.2)$ & $27(\mid 4.2)$ & $5(2.6)$ \\
\hline Washing hands before donning gloves & $87(45.8)$ & $65(34.2)$ & $38(20.0)$ \\
\hline Using hand sanitizer instead of washing & $61(32.1)$ & $84(44.2)$ & $45(23.7)$ \\
\hline \multicolumn{4}{|l|}{ Protective personal equipment } \\
\hline Wearing gloves while performing dental procedures & $167(87.9)$ & $17(8.9)$ & $6(3.2)$ \\
\hline Changing gloves between patients & $170(89.5)$ & $16(8.4)$ & $4(2.1)$ \\
\hline Using sterile surgical gloves for surgery & $121(63.7)$ & $36(18.9)$ & $33(17.4)$ \\
\hline Wearing protective eyewear & $68(35.8)$ & $62(32.6)$ & $60(31.6)$ \\
\hline Wearing mask & $150(78.9)$ & $20(10.5)$ & $20(10.5)$ \\
\hline Changing masks between patients & $90(47.4)$ & $62(32.6)$ & $38(20.0)$ \\
\hline Wearing disposable gowns for surgery & $84(44.2)$ & $46(24.2)$ & $60(31.6)$ \\
\hline Using high volume evacuation & $69(36.3)$ & $66(34.7)$ & $55(28.9)$ \\
\hline Using of single ampoules for local anaesthetic injections & $156(82.1)$ & $20(10.5)$ & $14(7.4)$ \\
\hline Asking your patient to do preoperative mouth rinses & $75(39.5)$ & $68(35.8)$ & $47(24.7)$ \\
\hline \multicolumn{4}{|l|}{ Disinfection and sterilization } \\
\hline Immersing used instruments in decontaminant solutions & $|3|(68.9)$ & $44(23.2)$ & $15(7.9)$ \\
\hline Sterilizing of hand pieces & $|4|(74.2)$ & $34(17.9)$ & $15(7.9)$ \\
\hline Sterilizing of burs & $158(83.2)$ & $25(13.2)$ & $7(3.7)$ \\
\hline Sterilizing of endodontic files & $160(84.2)$ & $21(I I . I)$ & $9(4.7)$ \\
\hline Use of wrapping bags for instrument sterilization & 149(78.4) & $30(15.8)$ & $\mathrm{II}(5.8)$ \\
\hline Use of surface barriers for dental unit surfaces & $107(56.3)$ & $45(23.7)$ & $38(20.0)$ \\
\hline Use of routine wiping for surface disinfection & |42(74.7) & $36(18.9)$ & $12(6.3)$ \\
\hline Chemical disinfection of impressions before sending to the laboratory & $123(64.7)$ & $3 I(16.3)$ & $36(18.9)$ \\
\hline Washing impressions with water before sending to the laboratory & $144(75.8)$ & $27(14.2)$ & $19(10.0)$ \\
\hline
\end{tabular}

\section{Practicing Disinfection and Sterilization}

Table 2 reveals that immersing used instruments in decontamination solution, sterilizing hand pieces, burs and endodontic files were performed frequently by the majority of the study sample $(68.9 \%, 74.2 \%, 83.2 \%$ and $84.2 \%$, respectively). About $78.0 \%$ of participants reported that they use wrapping bags for instrument sterilization; while a slightly less proportion $(74.7 \%)$ use routine wiping for the disinfection of surfaces in the dental care facility. Approximately, $56.0 \%$ of subjects reported that they use surface barriers for dental unit surfaces. Dental impressions were reported to be treated either by washing with water or chemical disinfection before sending to the laboratories by $76.0 \%$ and $64.7 \%$ of participants, respectively.

Table 4 presents practices of instrument sterilization and management of sharps waste. The majority of respondents $(90.5 \%)$ reported that they use an autoclave to sterilize instruments in their dental clinics. Moreover, $72.6 \%$ of participants immerse the used instruments in decontamination solution after treatment. About one half of respondents $(51.1 \%)$ reported that 1 week was the time since last maintenance of the sterilization devices. One week as a preferred time to use sterilized, wrapped packed instruments were reported by $72.1 \%$ of participants.

Table 5 shows that the participants from academic institutions use wrapping bags for instrument sterilization $\left(\chi^{2}=11.27 ; \mathrm{P}=0.027\right)$, surface barriers for dental unit surfaces $\left(\chi^{2}=21.76 ; \mathrm{P}<0.0001\right)$, and wash impressions with water before sending to laboratories $\left(\chi^{2}=19.61 ; \mathrm{P}<0.001\right)$ in lower frequencies compared to public and private dental clinics.

\section{Dealing with Sharp Instruments}

Table 4 shows that approximately $(81.0 \%)$ of participants reported that they have an appropriate protocol for emergency treatment of needle stick and other sharp accidents with significant differences between public hospitals $(90 \%)$ and academic institutions (69.4\%, $\chi^{2}=7.36$, $\mathrm{P}=0.025$ ) (Table 5). About $65.0 \%$ reported that they 
Table 3 Practice of Hand Hygiene and Use of PPE by Subgroups of the Study Sample

\begin{tabular}{|c|c|c|c|c|}
\hline \multirow[t]{2}{*}{ Demographic } & \multicolumn{3}{|c|}{$\begin{array}{l}\text { Practice of Hand Hygiene and Use } \\
\text { of PPE }\end{array}$} & \multirow[t]{2}{*}{$\begin{array}{l}\chi^{2} \text { value; } \\
\text { Sig }\end{array}$} \\
\hline & $\begin{array}{l}\text { Rarely } \\
\text { (N\%) }\end{array}$ & $\begin{array}{l}\text { Occasionally } \\
\text { N(\%) }\end{array}$ & $\begin{array}{l}\text { Always } \\
\mathbf{N}(\%)\end{array}$ & \\
\hline \multicolumn{5}{|c|}{ Washing hand before donning gloves } \\
\hline $\begin{array}{c}\text { Gender } \\
\text { Male } \\
\text { Female }\end{array}$ & $\begin{array}{l}7(9.9) \\
3 I(26.1)\end{array}$ & $\begin{array}{l}27(38.0) \\
38(31.9)\end{array}$ & $\begin{array}{l}37(52.1) \\
50(42.0)\end{array}$ & $7.3 ; 0.026$ \\
\hline \multicolumn{5}{|c|}{ Washing hands before starting treatment } \\
\hline $\begin{array}{l}\text { Profession } \\
\text { Dentist } \\
\text { Support } \\
\text { dental staff }\end{array}$ & $\begin{array}{l}6(4.9) \\
13(19.4)\end{array}$ & $\begin{array}{l}32(26.0) \\
13(19.4)\end{array}$ & $\begin{array}{l}85(69.1) \\
4 I(61.2)\end{array}$ & $10.63 ; 0.006$ \\
\hline \multicolumn{5}{|c|}{ Washing hands after treatment } \\
\hline $\begin{array}{l}\text { Educational } \\
\text { level } \\
\text { High school } \\
\text { or less } \\
\text { Diploma } \\
\text { Bachelor } \\
\text { Higher } \\
\text { education }\end{array}$ & $\begin{array}{l}0(0.0) \\
3(7.3) \\
2(2.0) \\
0(0.0)\end{array}$ & $\begin{array}{l}2(16.7) \\
11(26.8) \\
9(9.0) \\
5(13.5)\end{array}$ & $\begin{array}{l}10(83.3) \\
27(65.9) \\
89(89.0) \\
32(86.5)\end{array}$ & 13.37; 0.038 \\
\hline \multicolumn{5}{|c|}{ Using hand sanitizer instead of hand washing } \\
\hline $\begin{array}{l}\text { Mode of } \\
\text { practice } \\
\text { Specialty } \\
\text { General } \\
\text { practice }\end{array}$ & $\begin{array}{l}25(27.8) \\
20(20.0)\end{array}$ & $\begin{array}{l}28(31.1) \\
56(56.0)\end{array}$ & $\begin{array}{l}37(41.1) \\
24(24.0)\end{array}$ & $12.17 ; 0.002$ \\
\hline \multicolumn{5}{|c|}{ Preprocedural mouth rinsing } \\
\hline $\begin{array}{l}\text { Age (years) } \\
\begin{array}{l}<30 \\
30-39 \\
\geq 40\end{array}\end{array}$ & $\begin{array}{l}22(29.3) \\
16(25.4) \\
9(17.3)\end{array}$ & $\begin{array}{l}31(4 \mid .3) \\
24(38.1) \\
13(25.0)\end{array}$ & $\begin{array}{l}22(29.3) \\
23(36.5) \\
30(57.7)\end{array}$ & $10.7 ; 0.030$ \\
\hline \multicolumn{5}{|c|}{ Using high volume evacuation } \\
\hline $\begin{array}{l}\text { Practice type } \\
\text { Private } \\
\text { Academic } \\
\text { Public }\end{array}$ & $\begin{array}{l}17(20.2) \\
6(16.7) \\
32(45.7)\end{array}$ & $\begin{array}{l}25(29.8) \\
23(63.9) \\
18(25.7)\end{array}$ & $\begin{array}{l}42(50.0) \\
7(19.4) \\
20(28.6)\end{array}$ & $\begin{array}{l}30.23 \\
<0.0001\end{array}$ \\
\hline
\end{tabular}

maintain detailed records of such incidents. Furthermore, $88.4 \%$ of participants use puncture-resistant containers for sharp instruments with a significantly higher proportion of those who work in public hospitals (95.7\%) compared to those who work in academic institutions $\left(77.8 \%, \chi^{2}=7.81\right.$; $\mathrm{P}=0.020$ ) (Table 5).
Table 4 Sterilization, and Management of Sharps Waste $(N=190)$

\begin{tabular}{|c|c|}
\hline Variable & $\begin{array}{l}\text { Response } \\
\mathbf{N}(\%)\end{array}$ \\
\hline \multicolumn{2}{|l|}{$\begin{array}{l}\text { Which of the following do you use to sterilize } \\
\text { instruments in dental clinic }\end{array}$} \\
\hline Autoclave & $172(90.5)$ \\
\hline Boiling & $9(4.7)$ \\
\hline Washing & $6(3.2)$ \\
\hline Disinfectant solution & $3(1.6)$ \\
\hline \multicolumn{2}{|l|}{$\begin{array}{l}\text { When do you immerse the used instruments in } \\
\text { decontaminant solutions? }\end{array}$} \\
\hline Before treatment & $52(27.4)$ \\
\hline After treatment & 138(72.6) \\
\hline \multicolumn{2}{|l|}{$\begin{array}{l}\text { Time since last maintenance of the sterilization } \\
\text { devices }\end{array}$} \\
\hline One week & $97(51.1)$ \\
\hline Four weeks & $53(27.9)$ \\
\hline Six weeks & $20(10.5)$ \\
\hline Twelve or more weeks & $20(10.5)$ \\
\hline \multicolumn{2}{|l|}{$\begin{array}{l}\text { Preferred time of use of sterilized, wrapped } \\
\text { packed instruments }\end{array}$} \\
\hline One week & $137(72.1)$ \\
\hline Four weeks & $39(20.5)$ \\
\hline Six weeks & $8(4.2)$ \\
\hline Twelve or more weeks & $6(3.2)$ \\
\hline \multicolumn{2}{|l|}{$\begin{array}{l}\text { Having an appropriate protocol for emergency } \\
\text { treatment of needle stick or other sharp } \\
\text { accidents? }\end{array}$} \\
\hline Yes & $153(80.5)$ \\
\hline No & $37(19.5)$ \\
\hline \multicolumn{2}{|l|}{ Do you keep detailed records of these accidents? } \\
\hline Yes & $123(64.7)$ \\
\hline No & $67(35.3)$ \\
\hline \multicolumn{2}{|l|}{$\begin{array}{l}\text { Do you use puncture resistant container for } \\
\text { sharp instruments? }\end{array}$} \\
\hline Yes & 168(88.4) \\
\hline No & $22(11.6)$ \\
\hline
\end{tabular}

\section{Discussion}

In dental practices, an infectious disease can be transmitted in many routes such as direct contact with blood, oral fluids and other body secretions. Also, indirect contact with contaminated instruments, operatory equipment and environmental surfaces is very possible. ${ }^{14}$ Therefore, it is essential to adhere to the universally recommended guidelines in order to prevent cross-infection among dental health-care providers and patients as well as between patients themselves. This comprehensive study aimed to 
Table 5 Sterilization, and Management of Sharp Wastes by Work Type

\begin{tabular}{|c|c|c|c|c|}
\hline \multirow[t]{2}{*}{ Practice } & \multicolumn{3}{|c|}{ Work Type } & \multirow[t]{2}{*}{$\chi^{2}$ value; Sig. } \\
\hline & $\begin{array}{l}\text { Private } \\
\text { N(\%) }\end{array}$ & $\begin{array}{l}\text { Academic } \\
\mathbf{N}(\%)\end{array}$ & $\begin{array}{l}\text { Public } \\
\text { N(\%) }\end{array}$ & \\
\hline $\begin{array}{l}\text { Use wrapping bags for instrument sterilization } \\
\text { Rarely } \\
\text { Occasionally } \\
\text { Always }\end{array}$ & $\begin{array}{l}5(6.0) \\
10(11.9) \\
69(82.1)\end{array}$ & $\begin{array}{l}4(I I . I) \\
I I(30.6) \\
2 I(58.3)\end{array}$ & $\begin{array}{l}2(2.9) \\
9(12.9) \\
59(84.3)\end{array}$ & II.27; 0.027 \\
\hline $\begin{array}{l}\text { Use surface barriers } \\
\text { Rarely } \\
\text { Occasionally } \\
\text { Always }\end{array}$ & $\begin{array}{l}6(7.1) \\
19(22.6) \\
59(70.2)\end{array}$ & $\begin{array}{l}10(27.8) \\
13(36.1) \\
13(36.1)\end{array}$ & $\begin{array}{l}22(31.4) \\
13(18.6) \\
35(50.0)\end{array}$ & $21.76 ;<0.001$ \\
\hline $\begin{array}{l}\text { Washing impressions with water } \\
\text { Rarely } \\
\text { Occasionally } \\
\text { Always }\end{array}$ & $\begin{array}{l}2(2.4) \\
10(11.9) \\
72(85.7)\end{array}$ & $\begin{array}{l}10(27.8) \\
5(13.9) \\
21(58.3)\end{array}$ & $\begin{array}{l}7(10.0) \\
12(17.1) \\
51(72.9)\end{array}$ & $19.61 ; 0.001$ \\
\hline $\begin{array}{l}\text { Having protocol for emergency for needle stick/sharp accidents } \\
\text { Yes } \\
\text { No }\end{array}$ & $\begin{array}{l}65(77.4) \\
19(22.6)\end{array}$ & $\begin{array}{l}25(69.4) \\
\mathrm{II}(30.6)\end{array}$ & $\begin{array}{l}63(90.0) \\
7(10.0)\end{array}$ & $7.36,0.025$ \\
\hline $\begin{array}{l}\text { Using special container for sharp instruments } \\
\text { Yes } \\
\text { No }\end{array}$ & $\begin{array}{l}73(86.9) \\
\mathrm{II}(13.1)\end{array}$ & $\begin{array}{l}28(77.8) \\
8(22.2)\end{array}$ & $\begin{array}{l}67(95.7) \\
3(4.3)\end{array}$ & $7.81 ; 0.020$ \\
\hline
\end{tabular}

assess the level of infection-control practices of dental health-care providers including vaccination, hand hygiene, use of PPE, sterilization and disinfection in public hospitals, private clinics, and academic institutions in Jordan. In addition, the current study examined the correlations between socio-demographic and professional characteristics of the participants and their practice of infectioncontrol measures. In general, the study findings showed that the majority of the participants follow universal guidelines regarding vaccination against hepatitis B virus, using PPE, disinfection and sterilization, and dealing with sharp instruments. However, the self-reported infection-control practices did not reach optimal-desired levels.

Hepatitis B Virus is a well-recognized occupational risk in dental professionals, since it can be transmitted by exposure to blood and body fluids of an infected person. ${ }^{4}$ In this study, the majority of participants were vaccinated against hepatitis B $(82.1 \%)$, this is higher than that was reported by previous studies from Jordan $(36 \%)^{11}$ and Pakistan $^{15}(71.6 \%)$, and less than the findings of a study from New Zealand ${ }^{16}(94.2 \%)$, Italy $(85.7 \%)^{6}$ and Saudi Arabia $^{17}$ (90.6\%). The majority of hepatitis B nonvaccinated individuals was from dental support staff.
Lower frequency of hepatitis B vaccinations in dental support staff may be explained by lack of formal training and more frequent on-the-job training by dentists, especially in Jordan's private sectors. ${ }^{11}$

Good hand hygiene performed by dental practitioner is considered an effective method to prevent and control infection transmission in dental practice environment. ${ }^{4,18}$ This study showed that the majority of participants practice handwashing following patient treatment more than before starting treatment. Finding of this study is lower than a study conducted in Saudi Arabia that showed about $96.7 \%$ and $89.4 \%$ of the participants perform hand hygiene before and after contacting patients, respectively. ${ }^{17}$ However, in Pakistan, $\mathrm{Ch}$ et $\mathrm{al}^{15}$ reported that $79 \%$ of the participants wash their hands before and after treatment. The results of the current study showed that washing hands are affected by gender and academic degree. Males reported washing their hands before wearing gloves more than do females. In a study from Germany, it was reported that males conducted better hand hygiene than females after treatment, while females conduct correct hand hygiene more than males before treatment. ${ }^{18}$ However, some previous studies ${ }^{19-21}$ showed that females reported 
better hand hygiene practices than males. Dental support staff wash hands before treatment less frequently compared to dentists, and those with a diploma degree reported washing their hands after patient treatment less frequently than others in accordance with the conclusions of Mutters et $\mathrm{al},{ }^{18}$ who reported a lower compliance of dental assistants with infection-control procedures due to insufficient knowledge. The current findings showed dental care providers in specialty clinics use hand sanitizer for washing hands more than who work in general dental practice. In addition, participants who work in academic settings reported practicing handwashing less than those who work in private and public dental settings. The reason for such differences could be due to the pressure of work as a result of variations in the number of patient-care visits between the various settings.

Generating aerosols, droplets of water, saliva, blood, microorganisms, and other debris are very common during the performance of dental procedures. Therefore, disease transmission via travelling droplets and aerosol, which remain for a long time in the air, is a major concern in the dental environment. To minimize the susceptibility to airborne and blood born infections, dental care providers should adequately use PPE such as gloves, protective gowns, and face mask. ${ }^{1,4,18}$ The majority of respondents reported wearing gloves $(87.9 \%)$ and masks $(78.9 \%)$ frequently while performing dental procedures. The majority of participants $(89.5 \%)$ reported changing gloves between patients, however only $47.4 \%$ of them reported changing masks. This finding is similar to that of other studies. ${ }^{1,15,22}$ However, the reported proportions of the current study are higher than the findings of a previous study in Jordan, where $81.8 \%$ of participants reported that they wear and change gloves and $54.5 \%$ wear masks. ${ }^{11}$ Whereas a study from a South African Province ${ }^{23}$ shows that only 52.2\% and $65.25 \%$ of dental care providers reported wearing gloves and masks, respectively, while only $8.7 \%$ change gloves after each patient. The present findings also showed that wearing sterile surgical gloves, protective disposable surgical gown and use of high volume evacuation were reported to be less frequently practiced by participants. Yadav et $\mathrm{al}^{1}$ reported that $20 \%$ of the studied dentists use sterile surgical gloves, $10 \%$ use high volume evacuation, and $3.3 \%$ use protective gown. Using of high volume evacuation by the participants in private clinics is higher than that in public hospitals and academic institutions. This could be due to the fact that private clinics are usually more frequently inspected than public ones.
Patient-care items should be categorized and sterilized or disinfected depending on the potential risk for infection associated with their use. The study findings revealed that the majority of participants always perform disinfection and sterilization. Sterilization of hand pieces is performed by $74.2 \%$ of the participants, which is higher than that reported in a study from Tanzania $(54.2 \%)^{24}$ and lower than that in a study from New Zealand $(99.5 \%) .{ }^{16}$ In addition, results showed that surface disinfection for routine wiping was reported by $74.7 \%$, which is less than the findings that were reported in a study from Saudi Arabia $(95.1 \%)^{17}$ and higher than that reported from India. ${ }^{1}$ Participants from academic institutions reported that they use surface barriers less than reported by public hospitals and private clinics. This could be due to the unavailability of the materials or budget restrictions. Furthermore, $65 \%$ of the participants reported disinfecting impressions. This percentage is less than the findings from Saudi Arabia $(95.1 \%)^{17}$ and New Zealand $(71.8 \%){ }^{16}$ Significantly higher proportions of those worked at public hospitals and private clinics reported that they wash impressions with water before sending to laboratories more than those who worked at academic institutions. In general, the safety practices with respect to sterilization procedures were more adequate in public and private sectors than academic institutions. More investigations are needed to uncover the reasons behind such observation. In addition, frequent inspection of academic dental centres by the government is recommended.

Participants who are 40 years old and greater were more eager to perform disinfection and sterilization periodically in comparison with those younger than 30 years old. Participants with bachelor degree or higher showed significantly better disinfection and sterilization practices than those without certification, and work in private dental clinics. ${ }^{11}$ Thus, more training on safety guidelines should be applied to dental care providers, especially young and less educated.

Using autoclave for instrument sterilization is the preferred method due to its safety, rapid and lethal effect of pressurized steam on all microorganisms. ${ }^{1}$ The majority of participants reported using autoclave sterilization of dental instruments. This is in accordance with other studies, ${ }^{15,25}$ and higher than what was reported in a previous study in Jordan by Al-Omari and Al-Dawiri 63\%, ${ }^{11}$ whereas the findings of a study conducted by Banglani et $\mathrm{al}^{26}$ show that $76 \%$ of dental practitioners were using an autoclave. 
Although performing maintenance and monitoring of autoclaves is very important to ensure perfect sterilization cycle, ${ }^{1}$ only half of the participants reported performing the last maintenance of the sterilization devices within a period of 1 week. Therefore, it is recommended to increase the training and education in autoclave biosafety measures and periodic maintenance.

Many dental instruments are sharp and can cause injuries when handled such as needle sticks. This type of accident can be a potential source of infections. Needle stick injuries and sharp accidents should be prevented by following the recommended measures including implementing an emergency protocol, maintaining detailed reports, and safely disposing of sharp objects. ${ }^{1,4}$ The majority of participants reported appropriate protocol for emergency treatment of needle stick and sharp accidents. However, approximately $65 \%$ reported that they keep detailed records of those accidents compared to $10 \%$ in India ${ }^{1}$ and in Germany $35 \%$ by dentists and dental assistants $42 \%$, respectively. ${ }^{18}$ Using punctureresistant containers for sharp instruments was reported by most of the participants $(88.4 \%)$ which is higher than that was reported in a previous study in Jordan $(31.8 \%)^{11}$ and less than that was reported in Saudi Arabia (99.2\%). ${ }^{17}$ Although the overall practice in dealing with sharp objects among the study sample is good, it is recommended to optimize the performance of appropriate disposing protocols of sharp objects, compliance to the recommended guidelines during needle stick emergency, and maintaining detailed records of the accidents in the dental environment. Among the limitations of the current study is that the frequency of occupational infection and sharp injuries among examined population were not assessed. Therefore, future studies that include such measures are strongly recommended. Moreover, future similar studies should be conducted on a larger sample size.

\section{Conclusion}

The overall practice level of infection-control measures among dental care providers in Jordan is good. There is an improvement in the adherence of dental care providers to the universal guidelines of infection control compared to previous studies in Jordan. However, this level is not absolute as other studies have shown in various countries. Dental support staff showed less compliance with infection-control guidelines. Therefore, educational programs and training strategies should be implemented to maximize the compliance of dentists, as well as enhancing the compliance of dental support staff with infection-control guidelines.
Academic curricula should emphasize on infection-control practice, by including comprehensive theoretical and practical courses of the most current infection-control measures. Also, dental support staff should be certified in order to practice dental assisting and dental hygiene. Finally, consistent infection-control compliance evaluations of various dental environments by well-trained persons/specialized committee is highly recommended.

\section{Data Sharing Statement}

The data sets used during the current study are available from the corresponding author on reasonable request.

\section{Acknowledgment}

This project was supported by the Deanship of Research at Jordan University of Science and Technology. The authors declare that there is no conflict of interests.

\section{Disclosure}

The authors report no conflicts of interest in this work.

\section{References}

1. Yadav BK, Rai AK, Agarwal S, Yadav B. Assessment of infection control practice in private dental hospital. Int J Res Med Sci. 2017;5 (11):4737-4742. doi:10.18203/2320-6012.ijrms20174687

2. Taiwo J, Aderinokun G. Assessing cross infection prevention measures at the Dental Clinic, University College Hospital, Ibadan. Afr J Med Med Sci. 2002;31(3):213-217.

3. Aurangjeb AM, Zaman T, Badruddoza M. Practice of dental surgeons about dental splatter and aerosol. City Dent Coll J. 2013;10(2):10-16. doi:10.3329/cdcj.v10i2.16314

4. Kazi MM, Saxena R. Infection control practices in dental settings-a review. J Dent Allied Sci. 2012;1(2):67-71. doi:10.4103/22774696.159148

5. Gordon B, Burke F, Bagg J, Marlborough H, McHugh E. Systematic review of adherence to infection control guidelines in dentistry. J Dent. 2001;29(8):509-516. doi:10.1016/S0300-5712(01)00043-4

6. Di Giuseppe G, Nobile CG, Marinelli P, Angelillo IF. A survey of knowledge, attitudes, and behavior of Italian dentists toward immunization. Vaccine. 2007;25(9):1669-1675. doi:10.1016/j. vaccine.2006.10.056

7. DeCastro MG, Denys GA, Fauerbach LL, et al. APIC position paper: immunization. Am J Infect. 1999;27(1):52-53.

8. Mitchell R, Russell J. The elimination of cross-infection in dental practice-a 5-year follow-up. Br Dent J. 1989;166(6):209-211. doi:10.1038/sj.bdj. 4806775

9. Gershon RR, Karkashian C, Vlahov D, Grimes M, Spannhake E. Correlates of infection control practices in dentistry. Am J Infect. 1998;26(1):29-34.

10. Qudeimat MA, Farrah RY, Owais AI. Infection control knowledge and practices among dentists and dental nurses at a Jordanian university teaching center. Am J Infect. 2006;34(4):218-222.

11. Al-Omari MA, Al-Dwairi ZN. Compliance with infection control programs in private dental clinics in Jordan. J Dent Educ. 2005;69 (6):693-698. doi:10.1002/j.0022-0337.2005.69.6.tb03953.x 
12. Al-Dwairi ZN. Infection control procedures in commercial dental laboratories in Jordan. $J$ Dent Educ. 2007;71(9):1223-1227. doi:10.1002/j.0022-0337.2007.71.9.tb04388.x

13. Centers for Disease Control and Prevention. Guidelines for Infection Control in Dental Health-Care Settings. MMWR: Centers for Disease Control and Prevention. US Department of Health; 2003.

14. Ahmad IA, Rehan EA, Pani SC. Compliance of Saudi dental students with infection control guidelines. Int Dent J. 2013;63(4):196-201. doi:10.1111/idj.12030

15. Ch AN, Usman N, Kiran S, Zahra T, Khalid H, Akhtar MU. Cross infection control in dental institutions. Pak Oral Dent J. 2018;38 (4):419-422.

16. Lamb A, Hong C, De Silva H, Thomson W, Broadbent J. New Zealand oral health practitioners' cross-infection control practices. N Z Dent J. 2019;115(1):5-10.

17. AlAhdal A, Aljehani W, Ali G, Bayoumi A. Knowledge, attitude and practice of infection control measures in private dental clinics in Jeddah, Saudi Arabia. Int J Dent Oral Health. 2019;5(1):1-6.

18. Mutters NT, Hägele U, Hagenfeld D, Hellwig E, Frank U. Compliance with infection control practices in an university hospital dental clinic. GMS Hyg Infect Control. 2014;9(3):1-5.

19. McCarthy GM, Koval JJ, MacDonald JK, John MA. The role of age-and population-based differences in the attitudes, knowledge and infection control practices of Canadian dentists. Community Dent Oral Epidemiol. 1999;27(4):298-304. doi:10.1111/j.1600-0528.1999.tb02024.x
20. McCarthy GM, MacDonald JK. Gender differences in characteristics, infection control practices, knowledge and attitudes related to HIV among Ontario dentists. Community Dent Oral Epidemiol. 1996;24 (6):412-415. doi:10.1111/j.1600-0528.1996.tb00890.x

21. Osazuwa-Peters N, Chinedu Azodo C, Oluyemisi Ehizele A, Ndubuisi Obuekwe O. Gender differences in characteristics, occupational exposure, and infection control practices among dental professionals in Edo State, Nigeria. South Afr J Epidemiol Infect. 2012;27 (2):61-65. doi:10.1080/10158782.2012.11441486

22. Sukumaran P, Pin CW, Hong OZ, Mariam A. An audit of infection control practices amongst dental students in University of Malaya, Malaysia. Arch Orofac Sci. 2017;12(1):1-13.

23. Mehtar S, Shisana O, Mosala T, Dunbar R. Infection control practices in public dental care services: findings from one South African Province. J Hosp Infect. 2007;66(1):65-70. doi:10.1016/j.jhin. 2007.02.008

24. Christian M, Kikwilu EN. Knowledge, attitude, reported behaviour and perceived challenges to adhering to infection control measures in dental practice among dental practitioners in Tanzania. Tanzan Dent J. 2014;18(2):64-71.

25. Ahmed H. Methods of sterilization and monitoring of sterilization across selected dental practices in Karachi, Pakistan. $J$ Coll Physicians Surg Pak Oct. 2015;10:713-716.

26. Banglani MA, Punjabi SK, Banglani M. Cross infection control-A study. Pak Oral Dent J. 2016;36(2):286-288.
Clinical, Cosmetic and Investigational Dentistry

\section{Publish your work in this journal}

Clinical, Cosmetic and Investigational Dentistry is an international, peer-reviewed, open access, online journal focusing on the latest clinical and experimental research in dentistry with specific emphasis on cosmetic interventions. Innovative developments in dental materials, techniques and devices that improve outcomes and patient

\section{Dovepress}

satisfaction and preference will be highlighted. The manuscript management system is completely online and includes a very quick and fair peer-review system, which is all easy to use. Visit $\mathrm{http}: / / \mathrm{www}$.dovepress.com/testimonials.php to read real quotes from published authors. 